\title{
RDUS
}

Revue de DROIT

UNIVERSITÉ DE SHERBROOKE

Titre : $\quad$ LA PREUVE DES FAITS SOCIAUX ET LES BRANDEIS BRIEFS :

QUELQUES RÉSERVES

Auteur(s): $\quad$ Danielle PINARD

Revue : $\quad$ RDUS, 1995-1996, volume 26, numéro 2

Pages: $\quad 497-513$

ISSN : $\quad 0317-9656$

Éditeur : $\quad$ Université de Sherbrooke. Faculté de droit.

URI : $\quad$ http://hdl.handle.net/11143/12875

DOI : $\quad$ https://doi.org/10.17118/11143/12875 
Page vide laissée intentionnellement. 


\section{LA PREUVE DES FAITS SOCIAUX ET LES BRANDEIS BRIEFS : QUELQUES RÉSERVES}

par Danielle PINARD*

\section{SOMMAIRE}

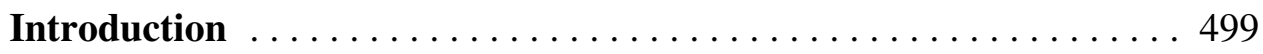

I. Le mémoire présenté par Louis Brandeis dans Muller v. Oregon, (1907) 208 U.S. $412 \ldots \ldots \ldots \ldots \ldots \ldots \ldots \ldots \ldots \ldots \ldots$

1. Louis Brandeis ..................... 500

2. L'affaire Muller v. Oregon, (1907) 208 U.S. 412 _ . . . 502

II. Quelques réserves $\ldots \ldots \ldots \ldots \ldots \ldots \ldots \ldots \ldots \ldots \ldots$

1. La question des femmes ............... 503

2. Le contenu et les modalités . . . . . . . . . . . . . . 505

3. L'objet de la présentation ............... 507

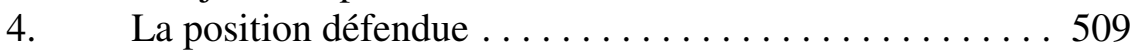

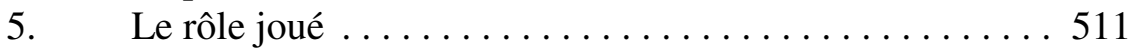

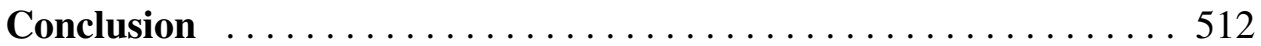

*. Professeure à la Faculté de droit de l'Université de Montréal. Le Fonds Marcel-Faribault de l’Université de Montréal a facilité la recherche nécessaire à la préparation de cette chronique. 


\section{Introduction}

Le mode de raisonnement judiciaire dans le contexte constitutionnel canadien a traditionnellement été conceptuel et abstrait. On a cependant aujourd'hui l'impression que, de plus en plus, des conclusions relatives à des faits de société sont au coeur de la décision constitutionnelle. On pense, par exemple, à des affirmations relatives à l'état de crise économique engendré par une situation d'inflation, ${ }^{1}$ à l'organisation du commerce des stupéfiants ${ }^{2}$ ou encore à l'impact de la publicité d'un produit sur sa consommation. ${ }^{3}$ Ces faits sociaux sont fondamentalement différents des faits particuliers ayant donné lieu à l'élaboration des règles traditionnelles de preuve. Ils sont incertains, objets d'approximations et d'évaluations.

Dans la discussion des modalités de présentation de ces faits aux tribunaux, ces documents que l'on désigne en droit américain et anglo-canadien comme les Brandeis Briefs sont souvent évoqués. Ils sont même parfois conçus comme la solution aux problèmes de preuve soulevés par l'incertitude inhérente aux faits sociaux : on les présente dans un Brandeis Brief, et le tour est joué! ${ }^{4}$

Le présent texte a pour objet de rappeler certaines caractéristiques du premier Brandeis Brief présenté en 1908 à la Cour suprême des États-Unis. Il vise, tout simplement, à inciter à la prudence celles et ceux qui s'en réclament aujourd'hui sans apporter les nuances qui s'imposent.

1. Renvoi : Loi anti-inflation, [1976] 2 R.C.S. 373.

2. R. c. Pearson, [1992] 3 R.C.S. 665.

3. R.J.R. MacDonald c. P.G. Canada, [1995] 3 R.C.S. 199.

4. La doctrine tient parfois pour acquises l'existence et la disponibilité des Brandeis Briefs pour la présentation de faits sociaux devant les tribunaux; voir, par exemple : G. S. PERRY et G. B. MELTON, «Precedential Value of Judicial Notice of Social Facts : Parham as an Example», (1983-84) 22 Journal of Family Law - University of Louisville School of Law 633, p. 640. Voir aussi R. LEMPERT, «"Between Cup and Lip", Social Science Influences on Law and Policy», (1988) 10 Law and Policy 167, p. 174. Voir enfin, dans une discussion relative à l'interprétation des lois, R. SULLIVAN, Driedgder on the Construction of Statutes, 3e édition, Toronto, Butterworths, 1994, p. 14. 


\section{Le mémoire présenté par Louis Brandeis dans Muller v. Oregon, (1907) 208 U.S. 412}

Dans cette première partie, je présenterai brièvement le juriste Brandeis, ainsi que le mémoire, devenu célèbre, présenté à la Cour suprême des États-Unis en 1908.

\section{Louis Brandeis}

Louis Dembitz Brandeis (1856-1941) reçut un diplôme de la Harvard Law School en $1878 .^{5}$

On le présente comme un juriste préoccupé par l'intégration du droit dans la réalité sociale. Pour lui, l'étude des fictions juridiques et des précédents judiciaires ne peut suffire à une compréhension intelligente du droit. Il considère que l'avocat, tout comme le juge, doit connaître précisément les faits visés par un domaine du droit, qu'il s'agisse d'une entreprise ou d'un commerce particulier. ${ }^{6}$ Seule une connaissance concrète et détaillée d'un secteur d'activités humaines permettra de comprendre et d'appliquer correctement les règles de droit pertinentes. ${ }^{7}$ «No law, written or unwritten, can be understood without a

5. On pourra consulter, par exemple : B. HALPERN, A Clash of Heroes, Brandeis, Weizmann and American Zionism, New York, Oxford University Press, 1987; A. T. MASON, Brandeis : A Free Man's Life, New York, Vicking Press, 1946; A. T. MASON, Brandeis : Lawyer and Judge in the Modern State, Princeton University Press, Princeton, 1933 (ciaprès Brandeis); M. E. DORO, «The Brandeis Brief», (1958) 11 Vanderbilt Law Review 783.

6. Brandeis, op. cit., p. 127.

7. Brandeis écrira par exemple, dans une opinion dissidente écrite dans Jay Burns Baking Co. v. Bryan, (1924) 264 U.S. 504, aux pages 519-520: «The determination of these questions involves an inquiry into facts. Unless we know the facts on which the legislators may have acted, we cannot properly decide whether they were (or whether their measures are) unreasonable, arbitrary or capricious. Knowledge is essential to understanding, and understanding should precede judging. Sometimes, if we would guide by the light of reason we must let out minds be bold. But in this case we have merely to acquaint ourselves with the art of bread-making and the usages of the trade, with the devices by which buyers of bread are imposed upon and honest bakers or dealers are subjected by their dishonest fellows to unfair competition, with the problems which have confronted public officials charged with the enforcement of the laws prohibiting short weights, and with their experience in administering those laws.» (nos italiques) 
full knowledge of the facts out of which it arises and to which it is to be applied», écrira-t-il. ${ }^{8}$

Comme avocat, Brandeis a pris soin de sensibiliser les juges devant qui il plaidait aux caractéristiques factuelles précises de la question en litige.

Cette sensibilité de l'avocat Brandeis à l'importance de la réalité factuelle pour l'activité du juriste a, semble-t-il, été l'un des éléments ayant alimenté la controverse relative à sa nomination à la Cour suprême des ÉtatsUnis. ${ }^{9}$ À ce propos, Lerner a élégamment exprimé cette idée selon laquelle on ne pouvait certes pas s'attendre à ce que Brandeis démontre une bienséante ignorance de la réalité extérieure :

«For whatever Mr. Justice Brandeis might or might not be expected to do, he could not be expected to cleave to the tradition that the whole duty of a Supreme Court justice was to maintain a decent ignorance of the world outside the Court.» ${ }^{10}$

Le juge Brandeis a été à la hauteur de cette prédiction. ${ }^{11}$ Il s'est constamment intéressé à la composante factuelle de tout litige qu'il avait à trancher, n'hésitant pas à aller s'informer lui-même, par exemple lorsqu'il était insatisfait de la présentation que lui avaient faite les parties. ${ }^{12}$ Fait remarquable, il allait même jusqu'à référer expressément, dans ses jugements, à ces recherches qu'il effectuait de façon autonome : le juge avait, selon lui, l'obligation de s'informer. Il écrira, dans Jay Burns Baking Co. v. Bryan ${ }^{13}$ :

«Much evidence referred to by me is not in the record. Nor could it have been included. It is the history of the experience gained under similar legislation, and the result of scientific experiments made since

8. L. BRANDEIS, «The Living Law», (1916) 10 Ill. L. Rev. 461, 467, cité dans Brandeis, op. cit., p. 179.

9. Brandeis, op. cit., p. 74. Son appartenance à la communauté juive a aussi été l'objet des discussions préalables à sa nomination; voir HALPERN, op. cit., note 5, pp. 103 et ss.

10. M. LERNER, «Social Thought of Mr. Justice Brandeis», (1931) 41 Yale L.J. 1, p. 11, cité dans DORO, loc. cit., note 5, p. 788.

11. Il fut nommé à la Cour suprême des États-Unis en 1916.

12. Brandeis, op. cit., note 5, pp. 176-177.

13. Jay Burns Baking Co. v. Bryan, précité, note 7. 
the entry of the judgment below. Of such events in our history, whether occuring before or after the enactment of the statute or of the entry of the judgment, the court should acquire knowledge, and must, in my opinion, take judicial notice, whenever required to perform the delicate judicial task here involved.» ${ }^{14}$

Il n'est donc pas surprenant que revienne à Louis Brandeis la paternité de cette technique de présentation de faits sociaux devant les tribunaux à laquelle on réfère aujourd'hui sous le vocable de Brandeis Brief.

\section{L'affaire Muller v. Oregon, (1907) 208 U.S. $412^{15}$}

Cette histoire du Brandeis Brief remonte à Muller v. Oregon, une cause dans laquelle était contestée devant la Cour suprême des États-Unis la constitutionnalité d'une loi de l'Oregon limitant à dix par jour les heures de travail des femmes dans certains secteurs d'activités. L'avocat Louis Brandeis a présenté en appel, au soutien de la validité de la loi, un dossier portant sur les dangers de longues heures de travail pour les femmes, et contenant des références à des lois semblables d'autres juridictions, à des discours politiques, à des rapports de différents comités, à des données statistiques et à des analyses de sciences médicales et sociales.

La principale difficulté rencontrée en cette cause par Louis Brandeis était la récente décision dans l'affaire Lochner, ${ }^{16}$ dans laquelle la même cour avait prononcé l'inconstitutionnalité d'une loi limitant le nombre d'heures hebdomadaires des travailleurs de boulangerie, et ce au nom de la liberté contractuelle constitutionnellement protégée. Afin de distinguer l'affaire Muller, Brandeis insista donc sur un aspect factuel spécifique : les particularités physiques des femmes justifiant, selon lui, un traitement législatif spécial en

14. Idem, p. 533, dans une opinion dissidente à laquelle le juge Holmes avait donné son appui.

15. Aussi rapporté à : (1907) 28 Supreme Court Reporter 324.

16. Lochner v. New York, (1905) 198 U.S. 45. 
matière de droit du travail. Se rendant aux arguments de Brandeis, ${ }^{17}$ la Cour a confirmé la validité constitutionnelle de la loi contestée. ${ }^{18}$

\section{Quelques réserves}

Afin de parer à une éventuelle tentation d'emprunter mécaniquement le concept du Brandeis Brief dans le but de solutionner les problèmes de preuve soulevés par la présentation des faits sociaux pertinents en contexte constitutionnel, il apparaît opportun de préciser certains aspects de sa présentation initiale.

\section{La question des femmes}

Les premières réserves que l'on peut entretenir à l'égard d'un recours mécanique au Brandeis Brief pour la présentation de faits sociaux devant les tribunaux sont suscitées par l'objet même de la cause discutée dans Muller v. Oregon. Suivant en cela la position défendue dans le mémoire de Brandeis, la Cour suprême des États-Unis y a confirmé la validité constitutionnelle de la loi limitant les heures de travail des femmes en invoquant principalement l'infériorité des femmes dans la lutte pour leur survie, l'intérêt de la société dans la protection de la race, et donc dans la force physique des femmes, et enfin par l'inexorable dépendance de ces dernières à l'égard des hommes. La Cour a de plus précisé qu'elle pouvait ainsi valider, dans son application aux femmes, une réglementation des heures de travail qu'elle avait par ailleurs dite invalide dans le cas des hommes, puisque les femmes constituaient une classe à part, ayant

17. La Cour a expressément référé en ces termes à l'argumentation inhabituelle présentée par Brandeis : «It may not be amiss, in the present case, before examining the constitutional question, to notice the course of legislation, as well as expressions of opinion from other than judicial sources. In the brief filed by Mr. Louis D. Brandeis for the defendant in error is a very copious collection of all these matters, an epitome of which is found in the margin.» Muller v. Oregon, précité, note 15, p. 325.

18. Il semble que l'utilisation du Brandeis Brief ait par la suite été en quelque sorte institutionnalisée en droit américain. Les paramètres en demeurent cependant incertains. Voir, par exemple : P.W. HOGG, Constitutional Law of Canada, Toronto, Carswell, 3e édition, 1992, p. 1294 : «However, despite the wide acceptance of the Brandeis brief in the United States, no clear rules have emerged as to when it is an appropriate vehicle of proof, as to the appropriate procedures to allow for rebuttal by the other side, or as to the weight to be given to "facts" in a Brandeis brief, which are inevitably less reliable than those adduced by sworn testimony.» 
besoin d'une protection particulière. L'extrait suivant du jugement en illustre fort bien le ton :

«Still again, history discloses the fact that woman has always been dependant upon man. He established his control at the outset by superior physical strength, and this control in various forms, with diminishing intensity, has continued to the present. [...] It is impossible to close one's eyes to the fact that she still looks to her brother and depends upon him. Even though all restrictions on political, personal and contractual rights were taken away, and she stood, so far as statutes are concerned, upon an absolutely equal plane with him, it would still be true that she is so constituted that she will rest upon and look for him for protection; that her physical structure and a proper discharge of her maternal functions - having in view not merely her own health, but the well-being of the race - justify legislation to protect her from the greed as well as the passion of man. The limitations which this statute places upon her contractual powers, upon her right to agree with her employer as to the time she shall labor, are not imposed solely for her benefit, but also largely for the benefit of all. Many words cannot make this plainer.» ${ }^{19}$

Les données présentées par Brandeis allaient dans ce sens. La Cour les résume en ces mots, empruntés à un inspecteur cité dans le mémoire de Brandeis : les justifications à la réduction des journées de travail des femmes sont les suivantes : a) la structure physique des femmes; b) leurs fonctions maternelles; c) l'éducation des enfants, et enfin d) l'entretien de la maison. ${ }^{20}$

Ces idées sur le statut des femmes et leur rôle dans la société n'étaient pas une invention du monde juridique. Elles étaient le produit d'une société donnée, à une époque donnée. Elles faisaient consensus, comme le font les préjugés généralement partagés dans une société.

Avec du recul, les «données» contenues dans le premier Brandeis Brief apparaissent comme les stéréotypes propres à une époque et non pas comme les fruits d'une production scientifique rigoureuse.

19. Précité, note 15, pp. 326-327.

20. Idem, p. 326. 
Il est d'ailleurs remarquable que la préparation de la cause ait été marquée du même type de conception des rapports hommes/femmes. ${ }^{21}$ Il semble en effet que l'intérêt dans la défense de la constitutionnalité de la loi de l'Oregon soit initialement venu du National Consumers' League, un mouvement de citoyens progressistes, et particulièrement, au sein de ce mouvement, de Florence Kelley et Josephine C. Goldmark. Ces dernières ont approché Brandeis à cette fin. Goldmark était en fait la belle-soeur de ce dernier. Brandeis a accepté d'assumer la défense de la loi, à la condition de représenter directement l'État de l'Oregon dans la cause, plutôt que d'agir comme simple amicus curiae. La collecte et la préparation des données factuelles, en l'espèce la plus importante partie du travail, ont été réalisées par Goldmark et une équipe de chercheurs travaillant sous sa supervision. Il semble que le Brandeis Brief finalisé comptait en fait deux pages d'argumentation juridique et plus d'une centaine de pages de présentation documentaire. $^{22}$ Peut-être eût-il été plus exact de référer au Goldmark Brief.

Historiquement, donc, le Brandeis Brief présenté dans Mullerv. Oregon, s'il a permis de limiter certains abus du laissez-faire économique sauvage à l'égard des femmes, ${ }^{23}$ l'a cependant fait en renforçant une idéologie sexiste et inégalitaire. De plus, l'important travail des femmes militantes dans la préparation du dossier n'y a reçu aucune reconnaissance, et la postérité n'a retenu que le nom du célèbre avocat ayant plaidé la cause.

\section{Le contenu et les modalités}

Le contenu hautement incertain des Brandeis Briefs constitue une autre source d'appréhension.

21. Sur cette question, voir notamment R. K.L. COLLINS et J. FRIESEN, «Looking Back on Muller v. Oregon», (1983) American Bar Association Journal 294 et 472 et Brandeis : A Free Man's Life, op. cit., note 5, pp. 248 et ss.

22. «Brandeis then outlined the material needed for his brief. The legal part he would himself cover in a few pages. For the economic and social data showing the evil of long hours and the possible benefits from legislative limitation, he would look to his sister-in-law. It was on these materials, not on the legal argument that he would base his case.» Brandeis : A Free Man's Life, op. cit., note 5, p. 248.

23. Il se peut cependant que la cause ait eu des effets pervers, comme le fait pour les employeurs des buanderies d'employer dorénavant des travailleurs chinois plutôt que des femmes : voir COLLINS et FRIESEN, loc. cit., note 21, p. 472. 
Une partie du Brandeis Brief présenté dans Muller contenait des lois de différents états américains et d'États étrangers qui prévoyaient aussi de telles limitations aux heures de travail des femmes. On y retrouvait enfin des passages de divers rapports, études et discours, nationaux et internationaux, contenant des affirmations plus ou moins documentées sur la santé des femmes et les effets de leurs heures de travail sur le bien-être général et les générations futures. ${ }^{24}$

Il ne faut donc pas se surprendre si les références actuelles au Brandeis Brief ne semblent y lire aucune limite de contenu. La version moderne du Brandeis Brief serait donc ce dossier que l'on joint en annexe à l'argumentation en droit, et qui contient, par exemple, des rapports d'études diverses, des résultats de recherches scientifiques relatives à certains faits sociaux, ou encore des données de sciences sociales, de type statistique ou autre. ${ }^{25}$ Hogg écrira, par exemple :

«[T]he Brandeis Brief can expose the court to a broad canvass of the state of social-science knowledge without the parties incurring the costs associated with a trial involving a lengthy parade of expert witnesses.» ${ }^{26}$

Généralement, les Brandeis Briefs sont tout simplement joints aux mémoires déposés à la cour. Il faut comprendre que cette façon de faire est

24. Pour un aperçu général du contenu du Brandeis Brief, voir J. MONAHAN et L. WALKER, Social Sciences in Law : Cases and Materials, 3e édition, New York, The Foundation Press, 1994, pp. 5-6-7. On y retrouve des rubriques aussi hétéroclites que : «Report of the Massachusetts State Board of Health», «International Conference in Relation to Labor Legislation, Berlin, 1890», «Proceedings of The French Senate, Session of July 7, 1891, M. Jules Simon» ou encore «President Roosevelt's Annual Message delivered to Second Session of 59th Congress, December 4, 1906».

25. Voir notamment B. G. MORGAN, «Proof of Facts in Charter Litigation», dans R. J. SHARPE (sous la direction de), Charter Litigation, Toronto, Butterworths, 1986, 159, pp. 177 et ss.; D. ALFANGE, «The Relevance of Legislative Facts in Constitutional Law», (1966) 114 University of Pennsylvania Law Review 637, pp. 667 et ss.; H. W. BIKLE, «Judicial Determination of Questions of Fact Affecting the Constitutional Validity of Legislative Action», (1924) 38 Harvard Law Review 6, p. 13 : «It [le Brandeis Brief] undertakes to bring before the Court, by inclusion in the brief of counsel, pertinent statistical data, legislative practice, scientific discussions by persons of eminence in their professions, departmental reports, and so forth, and to ask the Court to take judicial notice of the material so presented».

26. P.W. HOGG, op. cit., note 18, p. 1294. 
étrangère aux modes acceptés de preuve légale. ${ }^{27}$ L'information n'est ni présentée sous serment ni soumise au contre-interrogatoire, elle contrevient à la règle interdisant le ouï-dire, et on pourrait croire qu'elle ne rencontre généralement pas les critères traditionnels de la connaissance d'office.

De plus, il semble que le dossier soit conçu à des fins de présentation en appel, alors que le principe veut que les données factuelles soient d'abord présentées et évaluées en première instance, en conformité avec les règles de preuve. ${ }^{28}$

On ne peut pas dire que les faits discutés dans ces dossiers ont été prouvés de façon orthodoxe au tribunal. Tout au plus lui ont-ils été présentés.

On comprends certes l'intérêtt pour un plaideur de pouvoir présenter une importante quantité d'informations par le simple dépôt d'un document écrit. De prime abord, cependant, semblent se poser d'importantes questions d'arrimage au droit de la preuve.

\section{L'objet de la présentation}

L'étude de l'objet de la présentation initiale du Brandeis Brief incite aussi à la prudence et au scepticisme face à une utilisation débridée de la chose.

Le caractère limité de cet objet apparaît clairement à la lecture de la conclusion du mémoire historique de Louis Brandeis, qui se lit comme suit :

«[W]e submit that in view of the facts above set forth and of legislative action extending over a period of more than sixty years in the leading countries of Europe, and in twenty of our states, it cannot be said that the legislature of Oregon had no reasonable ground for believing that the public health, safety, or welfare did not [sic] require a legal

27. B.G. MORGAN, loc. cit., note 25, p. 179.

28. S. M. PILCHEN, «Politics v. The Cloister : Deciding When the Supreme Court Should Defer to Congressionnal Factfinding under the Post-Civil War Amendments», (1984) 59-1 Notre-Dame L. Rev. 337, 373 et suiv., p. 374, note 241. P.W. HOGG, op. cit., note 18, p. 1295. 
limitation on women's work in manufacturing and mechanical establishments and laundries to ten hours in one day.» ${ }^{29}$

Les données ont donc initialement été présentées, semble-t-il, non pas afin de convaincre le tribunal de leur véracité, mais plutôt afin de faire ressortir l'existence d'un fondement rationnel à l'action législative : elles démontraient qu'un législateur raisonnable pouvait supposer que la loi adoptée était appropriée afin de régler, ou à tout le moins de réduire le problème identifié.

L'avocat Brandeis aurait lui-même expliqué en ces termes, dans une autre cause cependant, que le défenseur de la constitutionnalité de la loi n'avait qu'à démontrer l'existence d'un fondement à une conclusion législative raisonnable quant aux moyens appropriés pour pallier un problème. Et ce, peu importe l'existence de données susceptibles de mettre en doute la sagesse de la solution législative ainsi adoptée :

«In answer to the question, whether this brief contains also all the data opposed to minimum-wage law, I want to say this : I conceive it to be absolutely immaterial what may be said against such laws. Each one of these statements contained in the brief in support of the contention that this is wise legislation, might upon further investigation be found to be erroneous, each conclusion of fact may be found afterwards to be unsound - and yet the constitutionality of the act would not be affected thereby. This court is not burdened with the duty of passing upon the disputed question whether the legislature of Oregon was wise or unwise, or probably wise or unwise, in enacting this law. The question is merely whether, as has been stated, you can see that the legislators had no ground on which they could, as reasonable men, deem this legislation appropriate to abolish or mitigate the evils believed to exist or apprehended. If you cannot find that, the law must stand.» ${ }^{30}$

29. Conclusion du mémoire présenté par Louis Brandeis dans Muller v. Oregon, précité, note 15, telle que rapportée dans MONAHAN et WALKER, op. cit., note 24, p. 7.

30. P. BREST, Processes of Constitutional Decisionmaking, Cases and Materials, Boston, Little, Brown and Company, 1975, p. 1007, citant P. FREUND, On Understanding the Supreme Court, 1949 : «Arguing as counsel in the Oregon minimum-wage case, Brandeis put the point in extreme terms : ( ... )», pp. 88-89. 
Il est donc primordial de retenir du concept original du dossier de faits sociaux de Louis Brandeis que les données ainsi présentées en contravention des règles traditionnelles de preuve l'étaient non point en vue de prouver la vérité des faits allégués, mais plutôt dans un but de démonstration de la rationalité de l'action législative. ${ }^{31}$

Il se peut donc que la plus grande facilité de leur présentation soit intimement liée à l'objet particulier de cette dernière. Ainsi, il n'est pas du tout certain que cette considération judiciaire de faits sociaux en violation des règles traditionnelles de preuve serait justifiée si, ce faisant, on tentait de démontrer leur vérité, et non plus la seule rationalité d'une croyance législative en leur existence. $^{32}$

Au minimum, ce déplacement de l'objet de preuve, de la simple croyance raisonnable en l'existence de certains faits, à l'existence même de ces faits, exigerait des aménagements en termes de rigueur et d'équité. De façon orthodoxe, cependant, on pourrait même arguer que la vérité relative à l'existence de certains faits ne peut être établie qu'en vertu des règles traditionnelles de preuve.

\section{La position défendue}

Dans toute discussion de la pertinence et de l'utilité des Brandeis Briefs, on ne doit pas oublier non plus la position au soutien de laquelle le mémoire a initialement été présenté.

Brandeis défendait la validité constitutionnelle de la loi contestée, et, on l'a vu, souhaitait tout simplement démontrer l'existence d'un fondement rationnel

31. Voir aussi, pour une telle interprétation : P.W. HOGG, op. cit., note 18, p. 1294. F.L. MORTON, Law, Politics and the Judicial Process in Canada, 2e édition, University of Calgary Press, 1992, p. 276. D. ALFANGE, loc. cit., note 25, p. 668. MONAHAN et WALKER, op. cit., note 24, p. 11. P. WEILER, «Two Models of Judicial Decision-Making», (1968) 46 R. du B. can. 406, 450.

32. P. BREST, op. cit., note 30, p. 940, citant P. FREUND, The Supreme Court of the United States 153 (1961) : «where data are used to prove the truth of the matters asserted, they "ought to be placed in the record and not left simply for the brief. If the data are presented for the record, there will be an opportunity ... in the trial court, to impeach or controvert the expert opinion that is relied on".» 
à l'action législative. ${ }^{33}$ On a même pu écrire qu'il s'agissait peut-être tout simplement de fournir un contexte factuel au jeu de la présomption de constitutionnalité. ${ }^{34}$

La souplesse autorisée pour la présentation des faits sociaux discutés dans les Brandeis Briefs est donc intrinsèquement liée à cet objet de preuve limité. $^{35}$

La question se pose donc quant à la possibilité de présenter un tel dossier, cette fois afin de contester la constitutionnalité d'une loi, notamment par la démonstration de son impact général. On doit noter une double distinction : d'une part, on n'est plus ici dans la mouvance de la présomption de constitutionnalité et, d'autre part, ce n'est plus le caractère rationnel d'une action législative qui est objet de preuve, mais bien l'existence factuelle et concrète d'effets inconstitutionnels. Par exemple, un individu doit démontrer la violation de ses droits et libertés, et non pas le seul caractère rationnel de sa croyance en l'existence de cette violation. La différence est considérable. ${ }^{36}$

Si la nature particulière des faits sociaux, réfractaires aux règles traditionnelles de preuve et peu susceptibles de faire l'objet d'allégations incontestablement vraies ou fausses, justifie à elle seule ce mode inusité de présentation devant le tribunal, l'ultime conclusion recherchée ne comptera pas.

33. D. ALFANGE, loc. cit., note 25, p. 668; P. A. FREUND, «Review of Facts in Constitutional Cases», dans E. CAHN (dir.), Supreme Court and Supreme Law, Bloomington, Indiana University Press, 1954, à la page 49.

34. K. L. KARST, «Legislative Facts in Constitutional Litigation», (1960) Sup. Ct. L. Rev. 75, 100. Voir aussi : D. ALFANGE, loc. cit., note 25, p. 668.

35. Sur les dangers accrus d'une utilisation erronnée de données de sciences sociales si ces dernières sont présentées afin d'obtenir une conclusion judiciaire quant à la vérité d'allégations relatives à certains faits plutôt que la détermination du caractère rationnel de l'action législative : K. SWINTON, «What Do the Courts Want From the Social Sciences», dans R.J. SHARPE, op. cit., note 25, p. 187, à la page 204 : «There is much more reason to fear the misuse or abuse of social science evidence if the courts are requiring that evidence in order for a party actually to prove a point than if the evidence is used to determine whether the legislature had a rational basis for its action.»

36. S. SCHIFF, Evidence on the Litigation Process, 3e édition, vol. 2, Toronto, Carswell, 1988, p. 711. F.L. MORTON, op. cit., note 31, p. 280, citant Weiler, «Two Models of Judicial Decision-Making», (1968) 46 Canadian Bar Rev. 406. 
On pourra alléguer l'existence de faits sociaux au moyen de dossiers Brandeis, et ce quelle que soit la position que l'on défend dans le litige constitutionnel.

$\mathrm{Si}$, au contraire, c'est plutôt une attitude judiciaire de retenue et de déférence à l'égard des choix législatifs qui fonde ce mode facilité de présentation factuelle, la partie qui conteste la constitutionnalité demeurera, elle, assujettie à la rigueur des règles traditionnelles de preuve.

Les tribunaux américains ont, semble-t-il, aussi accepté la présentation de tels dossiers en vue de la contestation de la constitutionnalité des lois. Il est cependant intéressant de remarquer qu'encore à ce jour on s'interroge sur l'utilisation que la Cour suprême des États-Unis a réellement faite de ces données contenues dans des Brandeis Briefs présentés à une telle fin. Dans Brown, par exemple, la Cour n'a en effet cité les études qui lui avaient été présentées afin de démontrer les effets préjudiciables de la ségrégation raciale en matière scolaire que dans une note de bas de page, laissant ainsi libre cours à des interprétations multiples et contradictoires. ${ }^{37}$

\section{Le rôle joué}

On peut finalement s'interroger sur le rôle réellement joué par le Brandeis Brief dans Muller v. Oregon. Il est vrai que la Cour en a expressément fait mention, ${ }^{38}$ et en a même résumé le contenu dans une note de bas de page. ${ }^{39}$ Elle a estimé qu'il démontrait l'existence d'un consensus social quant au fait que l'anatomie et les fonctions maternelles des femmes justifiaient un traitement

37. Voir, par exemple : K. SWINTON, «What Do the Courts Want From the Social Sciences», dans R.J. SHARPE, op. cit., note 25, p. 187, à la page 203. E. CAHN, «Jurisprudence», (1955) N.Y.L.R. 150, 160. B. WILSON, «Decision-making in the Supreme Court», (1986) 36 U.T.L.J. 227, p. 244 : re : Brown and social science data. «Although it is somewhat unclear as to whether the Court took an extremely liberalized view of the judicial notice rules based on the social science data, or whether these data were seen as factual proof of the detrimental effects of segregation on a balance of probabilities, it is clear that the expanded record greatly facilitated the judicial analysis, which would otherwise have entailed a great deal of guesswork.»

38. Muller v. Oregon, note 15, précité, p. 325.

39. Idem. 
législatif spécial quant à une limitation des heures de travail. ${ }^{40}$ Le propos significatif de la Cour est ici le suivant :

«At the same time, when a question of fact is debated and debatable, and the extent to which a special constitutional limitation goes is affected by the truth in respect to that fact, a widespread and longcontinued belief concerning it is worthy of consideration. We take judicial cognizance of all matters of general knowledge.» ${ }^{41}$

La Cour a donc tout simplement considéré ici que l'existence de particularités physiologiques des femmes était pertinente pour déterminer la constitutionnalité de la loi en cause, et qu'il lui était possible de prendre connaissance de l'existence d'un consensus social quant aux besoins engendrés par ces particularités.

On peut donc légitimement se demander si le Brandeis Brief a réellement influé sur l'issue de la décision, ou si la Cour n'a pas plutôt rendu une décision sur le fondement de ses propres a priori factuels, incidemment appuyés par les données qu'on lui a présentées. ${ }^{42}$

\section{Conclusion}

Dans un louable souci de réalisme, les tribunaux canadiens acceptent de plus en plus d'asseoir leurs jugements rendus en contexte constitutionnel sur des considérations relatives à des faits de société. Vu la difficulté de prouver ces derniers en vertu des règles habituelles, les tribunaux sont à la recherche de méthodes qui permettent à la fois la souplesse requise et le respect de l'équité du processus.

40. Idem, p. 326.

41. Idem.

42. Faigman écrira : «The absence of a Brandeis Brief in Muller probably would not have changed the result, nor would the presence of one have affected the Lochner result.» D. L. FAIGMAN, «Normative Constitutional Fact-Finding : Exploring the Empirical Component of Constitutional Interpretation», (1991) 139 University of Penn. L. Rev. 541, pp. 561-562. Selon cet auteur, la Cour a maintenu une théorie cohérente dans les deux décisions, selon laquelle l'État ne peut en principe limiter la liberté contractuelle, sauf à l'égard de certaines catégories de personnes. 
On comprend qu'il soit tentant d'invoquer de façon presque incantatoire le Brandeis Brief, un outil qui, apparemment, simplifie considérablement la tâche de présentation de faits de société aux tribunaux.

J'espère avoir démontré que l'exercice de transposition automatique est dangereux, en ce qu'il ignore certaines caractéristiques historiques essentielles du Brandeis Brief.

Il ne s'agit pas de nier toute pertinence au Brandeis Brief en droit constitutionnel canadien. Les références au Brief sont devenues trop nombreuses pour que l'on puisse en faire tout simplement abstraction dans l'étude des règles de preuve des faits sociaux en contexte constitutionnel. Il s'agit plutôt d'en connaître les origines et les caractéristiques initiales, et d'en limiter l'utilisation aux cas dans lesquels les règles de preuve du droit canadien le permettent.

Dans ce sens, une analyse plus traditionnelle des questions d'objet, de fardeaux et de moyens de preuve aidera certainement à préciser les paramètres de la pertinence des Brandeis Briefs en droit constitutionnel canadien.

Puisqu'on rattache parfois spontanément les Brandeis Briefs au concept de la connaissance d'office, ${ }^{43}$ l'étude de celui-ci s'avérera peut-être un premier pas prometteur. ${ }^{44}$

43. NOTE, «Social and Economic Facts - Appraisal of Suggested Techniques for Presenting Them to the Courts», (1948) 61 Harv. L. Rev. 692, 696. H.W. BIKLE, «Judicial Determination of Questions of Fact Affecting the Constitutional Validity of Legislative Action», (1924-25) 38 Harv. L. Rev. 6, 13. G. S. PERRY et G. B. MELTON, «Precedential Value of Judicial Notice of Social Facts : Parham as an Example», (1983) 22 Journal of Family Law 633, 640.

44. Voir D. PINARD, «Connaissance d'office», et «La connaissance d'office des faits sociaux en contexte constitutionnel», à paraître dans la Revue Juridique Thémis. 